\title{
Species diversity of drifting fish eggs in the Yangtze River using molecular identification
}

\author{
Mingdian Liu ${ }^{1}$ ， Dengqiang Wang ${ }^{1}$ ， Lei Gao ${ }^{1}$ ， Huiwu Tian ${ }^{1}$ ， Shaoping Liu ${ }^{1}$, Daqing Chen ${ }^{1}$, Xinbin Duan \\ ${ }^{1}$ Yangtze River Fisheries Research Institute of Chinese Academy of Fishery Science, Wuhan, Hubei, China \\ Corresponding Author: Xinbin Duan \\ Email address: duan@yfi.ac.cn
}

The dam constructions greatly changed the hydrologic conditions in the Yangtze River, and then significantly affected the spawning activities of indigenous river fish. Monitoring the species composition of drifting eggs during spawning season is important for protection issues. In this study, we have sampled drifting fish eggs in nine locations from 2014 to2016. Eggs were identified using mitochondrial cyt $b$ gene sequence. A total of 7, 933 fisheggsweresequencedsuccessfully and blasted into the NCBI database. Thirty-nine fish species were identified, and were assigned to four families and two orders. Approximately $64 \%$ of the species identified, and $67 \%$ of the eggs, were classified in the Family Cyprinidae. Abundance and Shannon-Wiener diversity index of species were higher in the main river than in tributaries of the river. However, tributaries may be important spawning grounds for some fish species. The Jaccard's similarity index and river-way distances among sampled stations were negatively correlated suggesting the environment shapes species composition in the sampled spawning grounds. These results showed that mitochondrial DNA sequence is a powerful and effective tool for fish egg identification in Yangtze River and these data are useful for conservation efforts. 


\title{
Species diversity of drifting fish eggs in the Yangtze River using molecular identification
}

\author{
Mingdian Liu; Dengqiang Wang; Lei Gao; Huiwu Tian; Shaoping Liu; Daqing Chen; Xinbin Duan \\ (Yangtze River Fisheries Research Institute of Chinese Academy of Fishery Science, Wuhan, Hubei 430223, \\ China)
}

\section{ABSTRACT}

The dam constructions greatly changed the hydrologic conditions in the Yangtze River, and then significantly affected the spawning activities of indigenous river fish. Monitoring the species composition of drifting eggs during spawning season is important for protection issues. In this study, we have sampled drifting fish eggs in nine locations from 2014 to 2016. Eggs were identified using mitochondrial cyt $b$ gene sequence. A total of 7, 933 fish eggs were sequenced successfully and blasted into the NCBI database. Thirty-nine fish species were identified, and were assigned to four families and two orders. Approximately $64 \%$ of the species identified, and $67 \%$ of the eggs, were classified in the Family Cyprinidae. Abundance and Shannon-Wiener diversity index of species were higher in the main river than in tributaries of the river. However, tributaries may be important spawning grounds for some fish species. The Jaccard's similarity index and river-way distances among sampled stations were negatively correlated suggesting the environment shapes species composition in the sampled spawning grounds. These results showed that mitochondrial DNA sequence is a powerful and effective tool for fish egg identification in Yangtze River and these data are useful for conservation efforts.

\section{CORRESPONDING AUTHOR}

Xinbin Duan, duan@yfi.ac.cn

\section{INTRODUCTION}

Monitoring fish spawning grounds in natural rivers provides useful information concerning fish habitat, spawning activity, and the effect of anthropogenic stressors. Data regarding spawning species, scale, and time are important for improving management and policy decisions.

The Yangtze River is the third largest river in the word. The section of the river above Yichang is generally called the "upper reaches" and the section from Yichang to Hukou is called the "middle reaches." In recent years, more dams have been constructed in the river, which seriously affect the spawning environment for fish. Such drastic ecological and environmental changes particularly affect fish that lay drifting eggs. There are approximately four hundred species of fish in the Yangtze River, and of these, approximately thirty species lay drifting eggs. Some of these fish are of commercial importance in China, such as grass carp (Ctenopharyngodon idella Valenciennes, 1844), black carp (Mylopharyngodon piceus Richardson, 1846), silver carp (Hypophthalmichthys molitrix Valenciennes, 1844), and bighead carp (Hypophthalmichthys nobilis Richardson, 1845); these are referred to as the four domestic Chinese carps (FDC) in China. The FDC spawning activities are controlled by temperature and hydrographs (Stanley 1978; Li et al. 2013), which shape more than 40 spawning grounds within mainstream regions of the Yangtze River. The mean annual egg production was over 100 billion in the 1960's (Yi and Liang 1964). The construction of the Gezhouba dam in the 1980s, and then the Three Gorges dam in the early 2000s have greatly changed the hydrologic conditions in the middle Yangtze River (Yi et al. 2010). These dam 
constructions significantly affected the spawning activities of indigenous river fish. The abundance of FDC larvae in the middle Yangtze River had decreased to 105 million in 2005 (Duan et al. 2009), and the spawning time was also delayed by approximately one month (Zhang et al. 2012). In addition, there are some species of fish that prefer certain river locations for spawning. For example, the largemouth bronze gudgeon, Coreius guichenoti Sauvage \& Dabry de Thiersant, 1874, primarily spawns in the lower of the Jinsha River, which is the main tributary of the Yangtze River (Cao et al. 2007). Impoundment of the Xiangjiaba dam in 2012 has destroyed the spawning ground of this species, and as a result no eggs or larvae have been found since then (Gao et al. 2015). If this species cannot find another suitable spawning ground, it is in danger of extinction (Cheng et al. 2015). Many tributaries of the Yangtze River are also distributed spawning grounds of fish that lay drifting eggs, and some of these fishes are endemic to one or several river sections (Xie et al. 2014; Cai et al. 2011; Wu et al. 2010).

Fishery resources in the Yangtze River have been undergoing a serious recession over the past 30 years (Chen et al. 2009; Huang \& Li, 2016). In an attempt to remedy the situation, the government has implemented measures to restore fish resources and the ecosystem. Several parameters include setting up protected regions, closed fishing seasons, releasing artificial fish into the river, and restricting fishing instruments (Chen et al. 2009). Monitoring spawning grounds could assess whether these measures have been successful. During the spawning season there may be more than a dozen or more species of fish spawning in the same location (Xie et al. 2014; Cai et al. 2011; Wu et al. 2010). Different species are associated with different nursery habitats and dispersal during early life history stages, and also have different protection requirements. Thus, quantifying and classifying fish eggs is crucial for conservation, management, and assessment of environmental effects. It is challenging to determine the species of the drifting eggs because most of the fish with this reproductive pattern have similar morphological characters in the early egg stages. In the past, several researchers tried to identify eggs species by size, color, oil droplets (Gao et al. 2010; Cao et al.2007; Yi et al. 1988), and couldn't obtain enough diagnosable information at species-level, because the egg size was variable and overlapping among most fishes, and the color was not so clear. Others tried to hatch eggs to identify distinguishable characteristics (Xu et al. 2015; Liu et al. 2014), however, it proved difficult to hatch eggs in the field.

Over the past decade, molecular identification methods have been increasingly used to deal within the limitations of morphological identifications for fish eggs. Mitochondrial DNA (mtDNA) DNA gene cytochrome c oxidase subunit I (COI) barcoding was proposed as a global DNA barcoding identification system for animals (Hebert et al. 2003a, b), based on the assumption of a so-called barcoding gap between species that intraspecific COI variation is lower than interspecific COI variation. At present, this approach has been used to the delimitation of various fishes (Hubert et al. 2010; Costa et al. 2012; Landi et al.2014; Frantine-Silva et al. 2015; Shen et al. 2016), eggs and larvae (Ahern et al.2018; Burghart et al. 2014; Harada et al. 2015; Lewis et al.2016; Ardura et al. 2016; Thompson, 2016). A fragment of mtDNA PCR restriction fragment length polymorphism (RFLP) was used for egg identification of European horse mackerel (Nikoletta et al.2010), the Atlantic cod (Gadus morhua Linnaeus, 1758) (Bui et al.2011), Antarctic fish (Fitzcharles 2012) and pelagic fish in the North Sea (Lelièvre et al. 2012). The mtDNA control region (D-loop) sequence was used to identify marine fish eggs in Taiwan (Shao et al. 2002) and pufferfish in the Sea of Japan for identification of spawning sites (Katamachi et al. 2015). The sequence of 16S rRNA gene successfully discriminated the pelagic fish eggs in the western North Pacific (Kawakami et al. 2010). Another mtDNA coding gene, cytochrome $b$ (cyt $b$ ), was broadly used as a marker for phylogeny in various taxonomic fishes (e.g. Peng et al. 2004; Zhang et al. 
2010), and also for species identification (Kartavtsev et al. 2007; Zhang et al. 2010). The gene has proven to be highly efficient and reliable for pelagic eggs in southeastern Australia (Neira et al. 2015).

In this study, we have applied cyt $b$ gene for identification of drifting fish eggs sampled from several spawning grounds in the Middle and Upper Yangtze River. The objective was to i) test identification efficiency of cyt $b$ gene for drifting eggs in the Yangtze River, and ii) to investigate species composition and distribution in different spawning grounds.

\section{MATERIALS AND METHODS Sampling location and egg collection}

May to July of each year is the spawning season for most fish in the Yangtze River. During this period in 2016, nine stations were set up to collect drifting fish eggs. These were the Yangtze River Panzhihua section (YPZ), the Yangtze River Jiangjin section (YJJ), the Yangtze River Yidou section (YYD), the Yangtze River Jingzhou section (YJZ), the Yangtze River Sanzhou section (YSZ), the Yangtze River Yanwo section (YYW), the Minjiang River Yibin section (MYB), the Chishui River Chishui section (CCS) and the Xiangjiang River Yingtian section (XYT) (Fig.1). Among these stations, the four stations of YPZ, YJJ, CCS and MYB were located in the upper reaches and the five stations of YYD, YJZ, YSZ, YYW and XYT in the middle reaches of the Yangtze River. Three stations, MYB, CCS and XYT were located in tributary rivers, and the other six stations were located in the main stream of the Yangtze River. Eggs were collected from YJJ in 2014 and 2015, and from YSZ and YYW in 2015. These collections were also used in this study.

Collecting nets and methods were described as Duan et al. (2009). Trap nets were put down in water at 6:00 to 9:30 and 16:00 to 19:00 every day during spawning season, and retrieved every 15 minutes. Each egg was recorded for morphological traits, such as developmental stage and size, and then preserved in a $2 \mathrm{~mL}$ EP tube with absolute ethanol.

The sampling work has been approved by the local related management departments named fishing administration supervision and administration station. This study is fully complied with the relevant laws and ethics of the country.

\section{DNA extraction, PCR}

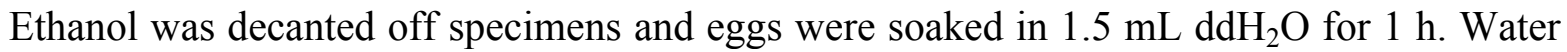
was then removed with a pipette, and egg genomic DNA was extracted using an easy-DNA Kit (Omega, Connecticut, USA).

Mitochondrial (mt) cyt $b$ gene was used as a molecular marker for species identification. The forward primer was L14322:5'-GAC TTG AAG AAC CAC CGT TGT TAT TCA AC-3' and the reverse primer H15576: 5'-GCG CTA GGG AGG AAT TTA ACC TCC-3'. PCR reactions had a final volume of $25 \mu \mathrm{l}$ and contained $2.5 \mu 110 \times$ PCR Buffer (TaKaRa, Dalian, China), $0.2 \mu 1$ of $10 \mathrm{mmol} / \mathrm{L}$ dNTPs, $1 \mu \mathrm{L}$ of each $10 \mu \mathrm{mol} / \mathrm{L}$ primers, $0.5 \mathrm{u}$ Taq enzyme ( TaKaRa, Dalian, China), $1 \mu 1$ of template DNA. The PCR reaction cycles were as follows: Pre-denaturation at $94{ }^{\circ} \mathrm{C}$ for $4 \mathrm{~min}, 35$ cycles of denaturation at $94{ }^{\circ} \mathrm{C}$ for $30 \mathrm{~s}$, annealing at $54{ }^{\circ} \mathrm{C}$ for $30 \mathrm{~s}$, extension at $72{ }^{\circ} \mathrm{C}$ for $90 \mathrm{~s}$, and a final extension at $72{ }^{\circ} \mathrm{C}$ for $8 \mathrm{~min}$.

PCR products were checked via $1.5 \%$ agarose gel electrophoresis and visualized with ethidium bromide to verify successful amplification. PCR DNA bands with expected size were purified using Cycle-Pure Kit (Omega, Connecticut, USA) and sequenced with the same primers as PCR (Tianyi biotech. Co. Ltd, Wuhan, China).

\section{Data analysis}

All sequences were aligned and trimmed to the same length using Muscle (Edgar 2004) in 
140 MEGA X (Kumar et al. 2018). Sequence properties of indels, frameshift mutations, in-frame stop 141 codons were careful examined to eliminate presence of pseudogene or nonfunctional sequences. 142 The genetic distance based on Kimura 2-parameter (Kimura, 1980) between the individuals were 143 calculated using MEGA X (Kumar et al. 2018) and a neighbor-joining tree (NJ tree) (Saitou and or lower of genetic distance and clustered as a monophyletic group in the NJ tree will be assigned to an operational taxonomic unit (OTU) and considered as a species. One or two sequences from each OTU were selected to compare with nucleotide sequences from GenBank (National Center for Biotechnology Information, NCBI) with the standard nucleotide BLAST (Basic Local Alignment Search Tool). Eggs were associated with a given species only if the similarity values were $98 \%$ or greater.

Species diversity of spawning ground was characterized using Shannon-Wiener diversity index (Schoener 1968). The Shannon-Wiener index is calculated as:

$\mathrm{H}^{\prime}=-\sum \mathrm{Pi} \ln \mathrm{Pi}$

Where pi is the proportion of species in total samples (egg numbers).

Similarities of species component between spawning grounds were evaluated by Jaccard's similarity index (JI) (Real and Vargas, 1996) using the formula JI $=a /(a+b+c)$, where ' $a$ ' is the number of species shared by two spawning ground, and ' $b$ ' and ' $c$ ' are the numbers of species specific in each spawning ground. Correlation between JI and the river-way distance was determined by the Mantel test with 1000 random permutations performed in Arlequin v3.1 (Excoffier and Lischer 2010).

\section{RESULTS \\ Species identification and diversity}

Overall, 8983 drifting eggs were recovered from the nine stations, of which 7,933 were sequenced successfully. All sequences were trimmed to the same length with $605 \mathrm{bp}$. A NJ tree, constructed to cluster species, revealed thirty-nine OTUs (Fig. 2). Comparing with sequences of adults and GenBank data, a total of 39 species were identified, representing 28 genera, 4 families, and 2 orders (Fig. 2, Table 1). The intraspecific and interspecific genetic distance range from 0 to 0.0288, and from 0.0308 (Botia superciliaris Günther, 1892- Botia reevesae Chang, 1944) to 0.3038 (Glyptothorax sinensis Regan, 1908- Pseudolaubuca engraulis Nichols, 1925), respectively (Showed in Supplement table). Approximately 64\% of the species and 67\% of eggs belonged to the Family Cyprinidae. In addition, 26\% of the species and 28\% of eggs were from the Family Cobitidae. The most commonly distributed species were the silver carp (H. molitrix), grass carp (C. idellus), silver gudgeon ( $S$. argentatus) and Yichang gudgeon (G. filifer). No fish species were found in all sampled stations.

The spawning ground with the highest species diversity was YJJ with 27 species identified, from 2014-2016. The next were YYD and YJZ, with 20 species found in both. The ShannonWiener $(\mathrm{H})$ diversity index of these three spawning grounds were greater than 2.0, and the other five were under 1.9. Stations with the lowest species diversity were YPZ, having 8 species.

\section{Species similarity among sites}

Pairwise Jaccard's similarity index and river-way distances among sampled stations are listed in Table 2. There are only one or two identical species among 19 to 28 species between YPZ and the four stations in the Middle Yangtze River (YYD, YJZ, YSZ, and YYW) and XYT station in the Xiangjiang River, which obtained the least JI values, ranging from 0 to 0.0952 . However, JI values among the four stations in the Middle Yangtze River had the highest values, ranging from 
0.5652 to 0.7391 .

A Strongly negative correlation was found between the JI and river-way distance (Mantel test, $\mathrm{R}=-0.9003)$.

\section{DISCUSSION}

In previous studies, Cao et al. (2007) and Li et al. (2013) have shown that approximately 25 species of fish lay drifting eggs in the Yangtze River. Here we identified 39 species from captured drifting fish eggs in seven sampled stations using the mitochondrial Cyt $b$ gene sequences. All obtained sequences had $98 \%$ identity with sequences in GenBank, indicating that reference data of the fish are available. Thus, fish eggs can successfully be identified to the species level. Intraspecific similarity of Cyt $b$ gene sequence was greater than $98 \%$, and interspecific distance higher than $2 \%$ for all these fish species. These studies indicate that mitochondrial sequence data are a power tool of species identification of drifting eggs in the Yangtze River, and may also contribute to identify rare or endangered species of fish. For example, some fish such as Saurogobio gymnocheilus Lo, Yao \& Chen, 1998, B. reevesae, Paracobitis potanini Günther, 1896, and Jinshaia abbreviata Günther, 1892, have had a low catch rate in recent years, but were detected in one or two spawning grounds in this study (Table 1). This observation may suggest that there are also smaller populations living in the river. However, two common fish species that lay drifting eggs in the Upper Yangtze River, C. guichenoti and Rhinogobio ventralis Sauvage \& Dabry de Thiersant, 1874 (Xiong et al. 2014; Liu et al. 2010; Xiong et al. 2016), were not found in this study. This may indicate that their spawning grounds were not in our monitoring stations. In addition, two recorded Leuciscin carps laying drifting eggs, Ochetobius elongatus Kner, 1867 (still found in Pearl River) and Luciobrama macrocephalus Lacepède, 1803 in the middle Yangtze River, were also not found from analysis of eggs. Since they have been not captured in recent years it is possible that these species are endangered to extinction in the Yangtze River.

Several species from the Culters genus were found in the collected eggs, such as Culter alburnus Basilewsky, 1855, Culter mongolicus Dybowski, 1872, and Cultrichthys erythropterus Basilewsky, 1855. Interestingly, these are not typical fish that lay drifting eggs. They generally spawn weakly viscous eggs among water plants or in river gravel and can also spawn in still water (Cao et al. 2008). They were detected in the YJJ station due to falling off from plants or gravels by river torrents. G. sinensis which is distributed in the Yangtze River and its tributaries and lakes, also produces viscous eggs not drifting, and their eggs usually adhere to stones in the water (Ding, 1994; Chu et al. 1999). Two eggs of G. sinensis were found in the YPZ station, where the current velocity could be greater than $2 \mathrm{~m} / \mathrm{s}$ (Xu et al. 2013).

The negative correlation between species similarity and river way distance reflected the diversity of ecological conditions in the Yangtze River. The nearer river stations have similar ecological characteristics, such as temperature, current velocity, and water flow, which attract more of the same fish to spawn. There are distinct differences in hydrology between the middle and upper reaches of the Yangtze River. The river is narrow, swift, and with a steep fall in elevation in the upper reaches compared with the wider, slower, and gradual fall in the middle reaches. Ecological differences shape the specificity of fish in the spawn ground. Six species, including Squaliobarbus curriculus Richardson, 1846, Elopichthys bambusa Richardson, 1845, Parabramis pekinensis Basilewsky, 1855, Pseudobrama simoni Bleeker, 1864, Xenocypris argentea Bleeker, 1871 and Parabotia banarescui Nalbant, 1965 are only found in the YYD, YJZ and/or YSZ, and YYW stations, consistent with their endemic presence in the middle Yangtze River. The upper 
232 Yangtze River involved fourteen species, including S. gymnocheilus, Hemiculterella sauvagei 233 Warpachowski, 1888, Xenophysogobio boulengeri Tchang, 1929, Xenophysogobio nudicorpa 234 Huang \& Zhang, 1986, Leptobotia rubrilabris Leptobotia rubrilabris,Dabry de Thiersant, 1872, 235 Leptobotia microphthalma Fu \& Ye, 1983, Leptobotia elongata Bleeker, 1870, B. reevesae, B. 236 superciliaris, P. potanini, Jinshaia sinensis Sauvage \& Dabry de Thiersant, 1874, and J. 237 abbreviate. Adults of L. elongate, the largest fish in the Family Cobitidae, were also found in the upstream should have crossed the Three Gorges Dam to the middle reaches of the river.

Species diversity of the YJJ station was shown to be the richest, and it harbored not only some importantly economic fish, such as FDC, also some unique fish, such as S. gymnocheilus (Table 1). This river reach is a very important spawning ground for fish laying drifting eggs. The numbers of species in the tributary river is less comparing with the Main River, but the rivers could be important spawning grounds for particular species. For example, the number of the small eye loach, L. microphthalma accounted for more than $86 \%$ of the total eggs in the MYB station, where in down reaches of Minjiang River. In the CCS station, located in the Chishui River, the species and egg numbers of species in the Family Cobitidae accounted for $50 \%$ and $36 \%$ of the total captures, respectively.

Though spawning and egg development of most of the fish identified in this study rely on running water, dependency levels were different. For example, FCD are apt to spawn in sudden floods (Duan et al. 2009, Li et al. 2011). However, spawning activity of G. filifer is negatively correlated with water discharge and water velocity (Tian et al. 2017). Understanding the composition of fish species at each spawning ground helps to assess the impact of environmental changes on fish, and molecular methods could be a useful tool for conducting this task effectively.

Our study presented a highly effective approach for rapid species identification of drifting eggs in Yangtze River, and it should due to reference data obtained in Genbank. A small percentage of collected eggs were not sequenced (approximately 11\%), which can be attributed to several errors along the path from collection to sequencing, such as improper egg preservation, DNA extraction and PCR failure. For large scale survey, the lab time as well as amplification and sequencing costs cannot to be ignored. Using high-throughput pipelines as an automatization of egg sorting, and a 96-well system for DNA extraction and for PCR amplification (Hofmann et al. 2017) and/or multiplex arrays (Gleason and Burton, 2012) is recommended. Another problem using a single gene of mtDNA for species identification is presence of heteroplasmy or incomplete lineage sorting within or among some species, which lead to aborted identification at species-level (Hubert et al.2008;April et al. 2011; Shen et al. 2016 ). Using more loci, for example COI, control region and ITS of rDNA, can improve the success rate of identification.

\section{CONCLUSIONS}

Mitochondrial DNA sequence is a powerful and effective tool for identifying species of drifting fish egg in Yangtze River. Species diversity in the main river is higher than that in tributaries, however some fish species prefer to spawn in tributaries.

\section{ACKNOWLEDGMENTS}

We thank International Science Editing (http://www.internationalscienceediting.com) for editing this manuscript.

\section{REFERENCES}

Ahern A, Gómezgutiérrez J, Aburtooropeza O, Saldierna-Martínez R, Johnson A, Harada A, Sánchez-Uvera 
A, Erisman B, Castro Arvizú D, Burton R. 2018. DNA sequencing of fish eggs and larvae reveals high species diversity and seasonal changes in spawning activity in the southeastern Gulf of California. Marine Ecology Progress, 592.

April J, Mayden R, Hanner R, Bernatchez L. 2011. Genetic calibration of species diversity among North America's freshwater fishes. Proceedings of the National Academy of Sciences of the United States of America, 108:10602-10607.

Ardura A, Morote E, Kochzius M, Garcia-Vazquez E. 2016. Diversity of planktonic fish larvae along a latitudinal gradient in the Eastern Atlantic Ocean estimated through DNA barcodes. Peerj, 4(3):e2438.

Baldwin C, Brito B, Smith D, Weigt L, Escobar-Briones E. 2011. Identification of early life-history stages of Caribbean apogon (Perciformes: Apogonidae) through DNA Barcoding. Zootaxa, 3133, 1-36.

Bui A, Castonguay M, Ouellet P, Sévigny J. 2011. Searching for Atlantic cod (Gadus morhua) spawning sites in the northwest Gulf of St Lawrence (Canada) using molecular techniques. Ices Journal of Marine Science, 68(5):911-918.

Burghart S, Woudenberg L, Daniels C, Meyers S, Peebles E and Breitbart M. 2014. Disparity between planktonic fish egg and larval communities as indicated by DNA barcoding. Marine Ecology Progress, 503(1):195-204.

Cao W, Chang J, Qiao Y, Duan Z. 2007. Fish resources of early life history stages in Yangtze River, China. Water Power Press, Beijing.

Chen D, Xiong F, Wang K, Chang Y. 2009. Status of research on Yangtze fish biology and fisheries. Environmental Biology of Fishes, 85(4):337-357.

Cheng F, Li W, Castello L, Murphy B, Xie S. 2015. Potential effects of dam cascade on fish: lessons from the Yangtze River. Reviews in Fish Biology and Fisheries, 25(3):569-585.

Chu X, Zhen B, Dai D. 1999. Fauna Sinica, Osteichthyes, Siluriforms. Beijing: Science Press, 133-135.

Costa F, Landi M, Martins R, Costa M, Costa M, Carneiro M, Carvalho G. 2012. A ranking system for reference libraries of DNA barcodes: Application to marine fish species from Portugal. PLoS ONE, 7, e35858.

Ding R. 1994. Sichuan fish fauna. Sichuan Science and Technology Press, 481-484.

Duan X, Liu S, Huang M, Qiu S, Li Z, Wang K, Chen D. 2009. Changes in abundance of larvae of the four domestic Chinese carps in the middle reach of the Yangtze River, China, before and after closing of the Three Gorges Dam. Environmental Biology of Fishes, 86(1):13-22.

Edgar R C.2004. MUSCLE: multiple sequence alignment with high accuracy and high throughput. Nucleic Aci ds Research, 32(5):1792-1797.

Excoffier L, Lischer H. 2010. Arlequin suite ver 3.5: a new series of programs to perform population genetics analyses under Linux and Windows. Molecular Ecology Resources, 10, 564-567.

Felsenstein J. 1985. Confidence limits on phylogenies: An approach using the bootstrap. Evolution 39:783-791.

Fitzcharles E. 2012. Rapid discrimination between four Antarctic fish species, genus Macrourus, using HRM analysis. Fisheries Research, 127-128: 166-170.

Frantine-Silva W, Sofia S, Orsi M, Almeida F. 2015. DNA barcoding of freshwater ichthyoplankton in the Neotropics as a tool for ecological monitoring. Molecular Ecology Resources, 15(5):1226-1237.

Gao X, Zeng Y, Wang J, Liu H. 2010. Immediate impacts of the second impoundment on fish communities in the Three Gorges Reservoir. Environmental Biology of Fishes, 87:163-173.

Gao S, Tang H, Chen S. 2015. Effects of the first phase of Jinsha River Hydropower Project on fish Recruitment: early life history Stages of Coreius guichenoti in the Upper Yangtze River. Journal of Hydroecology, 36(2):6-10.

Gleason L, Burton R. 2012. High-throughput molecular identification of fish eggs using multiplex suspension bead arrays. Molecular Ecology Resources, 12(1):57-66.

Harada A, Lindgren E, Hermsmeier M. 2015. Monitoring spawning activity in a southern California Marine Protected Area using molecular identification of fish eggs. Plos One, 10(8): e0134647

Hebert P, Cywinska A, Ball S, deWaard J. 2003a. Biological identifications through DNA barcodes. Proceedings Biological Sciences, 270 (1512): 313-321.

Hebert P, Ratnasingham S, Waard J. 2003b. Barcoding animal life: cytochrome c oxidase subunit 1 divergences among closely related species. Proceedings Biological Sciences, 270 (Suppl_1): S96.

Hofmann T, Knebelsberger T, Kloppmann M, Ulleweit J, Raupach M J. 2017. Egg identification of three economical important fish species using dna barcoding in comparison to a morphological 
332

333

determination. Journal of Applied Ichthyology, 33(5), 925-932.

Huang L, Li J. 2016. Status of freshwater Fish biodiversity in the Yangtze River Basin, China. Aquatic Biodiversity Conservation and Ecosystem Services. Springer Singapore.

Hubert N, Delrieu-Trottin E, Irisson J O, Meyer C, Planes S. 2010. Identifying coral reef fish larvae through DNA barcoding: A test case with the families Acanthuridae and Holocentridae. Molecular Phylogenetics and Evolution, 55, 1195 - 1203.

Hubert N, Hanner R, Holm E, Mandrak N, Taylor E, Burridge M, Watkinson D, Dumont P, Curry A, Bentzen P, Zhang J, April J, Bernatchez L. 2008. Identifying Canadian freshwater fishes through DNA barcodes. PLoS One 3:e2490.

Kartavtsev Y, Park T, Vinnikov K, Ivankov V, Sharina S, Lee J. 2007. Cytochrome $b$, (Cyt- $b$ ) gene sequence analysis in six flatfish species (Teleostei, Pleuronectidae), with phylogenetic and taxonomic insights. Marine Biology, 152(4):757-773.

Katamachi D, Ikeda M, Uno K. 2015. Identification of spawning sites of the tiger puffer Takifugu rubripes, in Nanao Bay, Japan, using DNA analysis. Fisheries Science, 81(3):485-494.

Kawakami T, Aoyama J, Tsukamoto K. 2010. Morphology of pelagic fish eggs identified using mitochondrial DNA and their distribution in waters west of the Mariana Islands. Environmental Biology of Fishes, 87(3):221-235.

Kimura M. 1980. A simple method for estimating evolutionary rate of base substitutions through comparative studies of nucleotide sequences. Journal of Molecular Evolution, 16:111-120.

Kumar S, Stecher G, Li M. 2018. MEGA X: Molecular evolutionary genetics analysis across computing platforms. Molecular Biology \& Evolution. 35: 1547-1549.

Landi M, Dimech M, Arculeo M, Biondo G, Martins R, Carneiro M, Carvalho GR, Brutto SL, Costa FO. 2014. DNA Barcoding for Species Assignment: The Case of Mediterranean Marine Fishes. PloS One, 9(9):e106135.

Lelièvre S, Jérôme M, Maes G, Vaz S, Calaivany S, Verrez-Bagnis V. 2012. Integrating molecular identification of pelagic eggs with geostatistical mapping to improve the delineation of North Sea fish spawning grounds. Marine Ecology Progress, 445(1):161-172.

Lewis LA, Richardson DE, Zakharov EV, Hanner R. 2016. Integrating DNA barcoding of fish eggs into ichthyoplankton monitoring programs. Fishery Bulletin.114: 153-165.

Li M, Gao X, Yang R, Duan Z, Cao W. 2013. Effects of environmental factors on natural reproduction of the four major Chinese carps in the Yangtze River, China. Zoological Science, 30(4):296-303.

Li W, Cai Y, Tang Y. 2011. Preliminary study on the larval resources of fishes spawning drifting eggs in the middle and lower reaches of the Hanjiang River. Journal of Hydroecology, 32:53-57.

Liu F, Li L, Liu H. 2014. Diel drifting pattern of fish eggs in Chishui section of the Chishui River. Freshwater Fisheries, 44(6):87-91.

Neira F, Perry R, Burridge C, Lyle J, Keane J. 2015. Molecular discrimination of shelf-spawned eggs of two co-occurring Trachurus spp. (Carangidae) in southeastern Australia: a key step to future egg-based biomass estimates. Ices Journal of Marine Science, 72(2):614-624.

Nikoletta K, Alexer T, Paula A, Placida L, Eva G. 2010. Horse mackerel egg identification using DNA methodology. Marine Ecology, 28(4):429-434.

Peng Z, He S, Zhang Y. 2004. Phylogenetic relationships of glyptosternoid fishes (Siluriformes: Sisoridae) inferred from mitochondrial cytochrome b gene sequences. Molecular Phylogenetics and Evolution, 31(3):979-987.

Real R, Vargas J. 1996. The probabilistic basis of Jaccard's Index of Similarity. Systematic Biology, 45(3):380385.

Saitou N, Nei M. 1987. The neighbor-joining method: a new method for reconstructing phylogenetic trees. Molecular Biology \& Evolution, 4:406-425.

Schoener T. 1968. The Anolis lizards of Bimini: Resource partitioning in a complex fauna. Ecology, 49:704726.

Shao K, Chen K, Wu J. 2002. Identification of marine fish eggs in Taiwan using light microscopy, scanning electric microscopy and mtDNA sequencing. Marine and Freshwater Research, 53(2):355-365.

Shen Y, Guan L, Wang D, Gan X. 2016. Dna barcoding and evaluation of genetic diversity in cyprinidae fish in the midstream of the yangtze river. Ecology \& Evolution, 6(9), 2702-2713. 
Thompson A. 2016. Rockfish assemblage structure and spawning locations in southern California identified through larval sampling. Marine Ecology Progress, 547:177-192.

Tian H, Wang H, Gao T, Dong W, Lv, Chen D, Duan X. 2017. Early resources of Gobiobotia filifer and its relationship with environmental factors in the upper Yangtze River. Freshwater Fisheries, 47(2):71-78.

Wibowo A, Wahlberg N, Vasemägi A. 2017. DNA barcoding of fish larvae reveals uncharacterised biodiversity in tropical peat swamps of New Guinea, Indonesia. Marine and Freshwater Research, 68(6):1079-1087.

Wu J, Wang Q, Liu F. 2010. Fish resources of early life in Chishui section of the Chishui River. Resources \& Environment in the Yangtze Basin, 19(11):1270-1276.

Xie W, Tang H, Huang D, Yang Z, Yang H. 2014. The current status of spawning grounds for fishes spawning as pelagic eggs in reaches from Qiyang to Hengnan in Xiangjiang River. Fisheries Science, 2: 103-107.

Xiong F, Liu H, Duan X, Liu S, Chen D. 2014. Stock Assessment of Coreius guichenoti in Jiangjin and Yibin Sections of the Upper Yangtze River. Chinese Journal of Zoology, 49(6):852-859.

Xiong F, Liu H, Duan X, Liu S, Chen D. 2016. Estimating population abundance and utilization of Rhinogobio ventralis, an endemic fish species in the upper Yangtze River. Biodiversity Science, 24 (3): 304-312.

Xu W, Qiao Y, Chen X, Cai Y, Yang Z. 2015. Spawning activity of the four major Chinese carps in the middle mainstream of the Yangtze River, during the Three Gorges Reservoir operation period, China. Journal of Applied Ichthyology, 31(5):1-1.

Xu X, Wang G, Fu H. 2013. Study on impact from hydropower planning on hydrological regime of Panzhihua Reach of Jinshajiang River. Water Resources and Hydropower Engineering, 44(2):2-4.

Yi B, Liang Z. 1964. Natural conditions and major external factors contributing to spawning in the Yangtze River domestic fish spawning grounds. Aquatic biology collection, 5(1): 1-15.

Yi B, Yu Z, Liang Z. 1988. A comparative study of the early development of grass carp, black carp, silver carp and big head of the Yangtze River. In: Yi B, Yu Z, Liang Z (eds) Gezhouba Water Control Project and four domestic fishes in Yangtze River. Hubei Science and Technology Press, Wuhan, China, 69-116.

Yi Y, Wang Z, Yang Z. 2010. Impact of the Gezhouba and Three Gorges Dams on habitat suitability of carps in the Yangtze River. Journal of Hydrology, 387(3-4):283-291.

Zhang G, Wu L, Li H. 2012. Preliminary evidence of delayed spawning and suppressed larval growth and condition of the major carps in the Yangtze River below the Three Gorges Dam. Environmental Biology of Fishes, 93(93):439-447.

Zhang J, Li M, Xu M, Takita T, Wei F. 2010. Molecular phylogeny of icefish Salangidae based on complete mtDNA cytochrome b sequences, with comments on estuarine fish evolution. Biological Journal of the Linnean Society, 91(2):325-340.

Fig.1 Location of nine sample stations (YPZ, MYB, CCS, YJJ, YYD, YJZ, YSZ, YYW, XYT) and species composition in Family 1-Gezhouba Dam, 2- Three Gorges Dam, 3- Xiangjiaba Dam

Fig. 2 Neighbour-Joining tree of 8,983 fish eggs using mtDNA cyt $b$ gene. Bootstrap values for 1,000 replicates are shown on nodes, and support rates below $50 \%$ were cut off. Numbers in brackets are the amount of eggs sampled.

Supplement Table: The intraspecific and interspecific genetic distance based on Kimura 2-parameter model in this study. Values with underline showed the maxium intraspecific distance. 
Figure 1

Location of nine sample stations and species composition in Family

1-Gezhouba Dam, 2- Three Gorges Dam, 3- Xiangjiaba Dam.

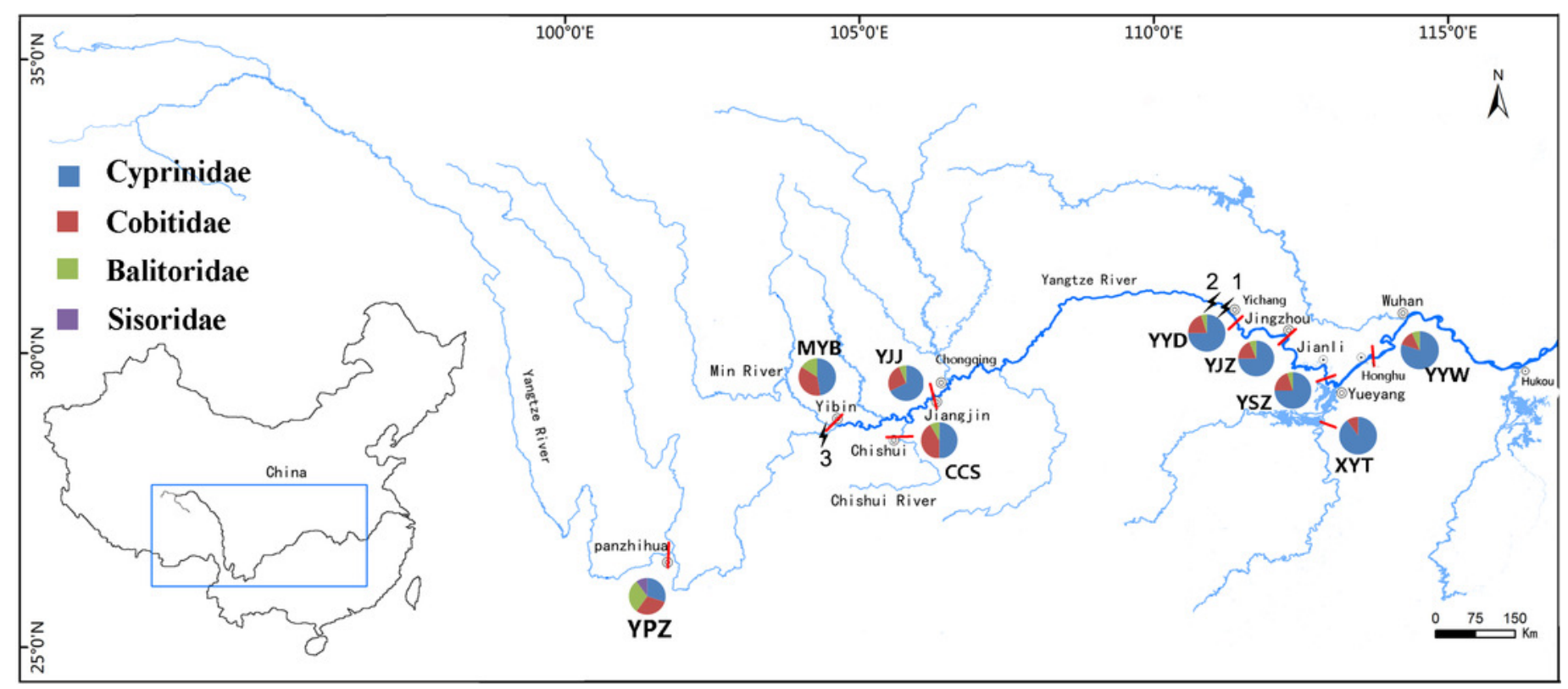


Figure 2

Neighbour-joining tree of 8,983 fish eggs using mtDNA cyt $b$ gene. 


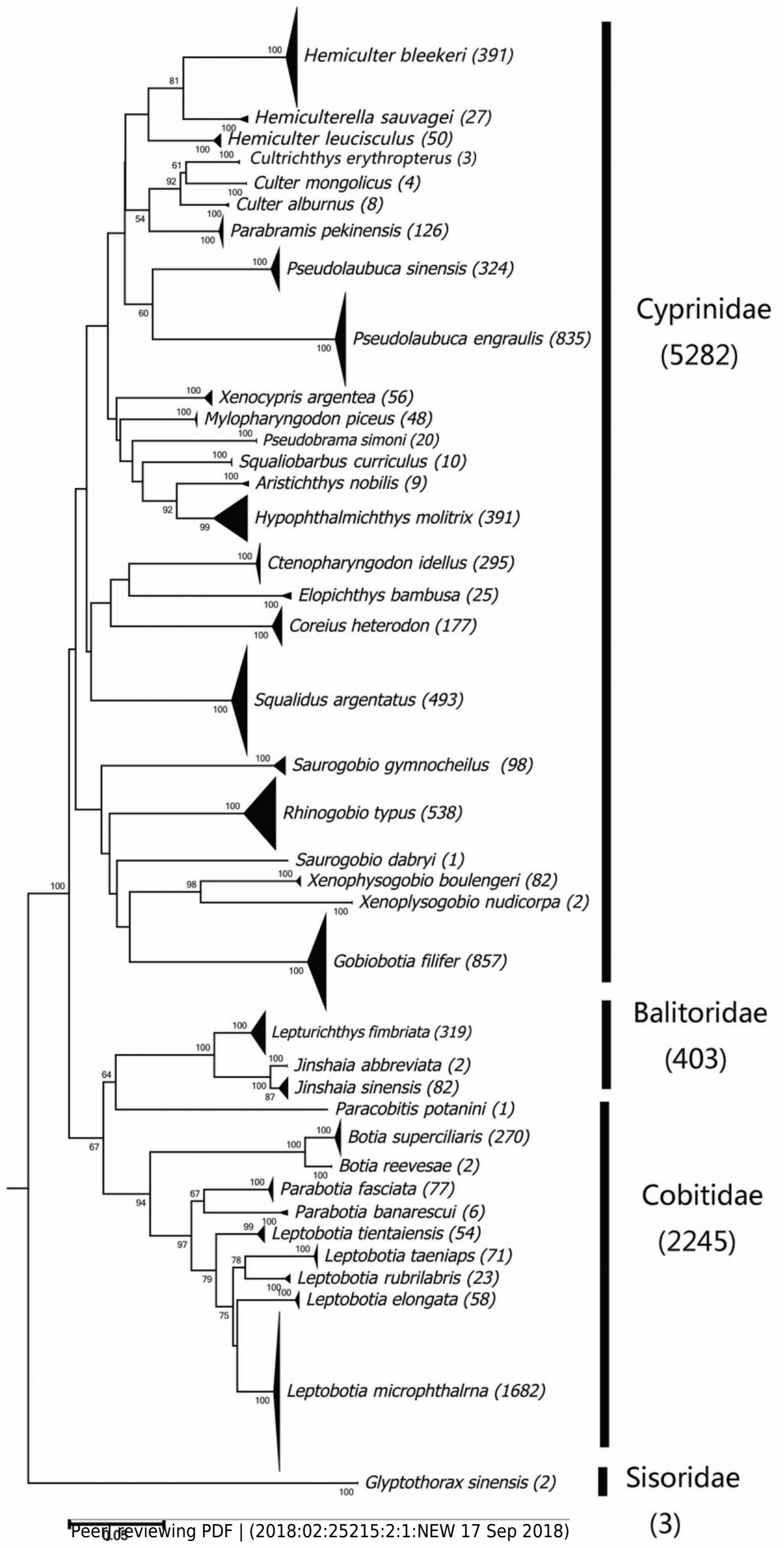




\section{Table 1 (on next page)}

Species composition and diversity in nine sampled stations of the Yangtze River 
1 Table 1 Species composition and diversity in nine sampled stations of the Yangtze River

\begin{tabular}{|c|c|c|c|c|c|c|c|c|c|c|c|c|c|c|c|c|c|c|c|}
\hline \multirow{3}{*}{ Orders } & \multirow{3}{*}{ Families } & \multirow{3}{*}{ Species } & \multicolumn{13}{|c|}{ Stations \& Years } & \multirow{3}{*}{$\begin{array}{l}\text { Total } \\
\text { number } \\
\text { of eggs }\end{array}$} & \multirow{3}{*}{$\begin{array}{c}\text { Ratio } \\
(\%)\end{array}$} & \multicolumn{2}{|c|}{ GenBank } \\
\hline & & & \multirow{2}{*}{\begin{tabular}{|r|} 
YPZ \\
2016 \\
\end{tabular}} & \multirow{2}{*}{$\begin{array}{l}\text { MYB } \\
2016 \\
\end{array}$} & \multirow{2}{*}{$\begin{array}{r}\text { CCS } \\
2016 \\
\end{array}$} & \multicolumn{3}{|l|}{ No. } & \multirow{2}{*}{\begin{tabular}{|l|} 
No. \\
2015 \\
\end{tabular}} & \multirow{2}{*}{$\begin{array}{r}\text { YJZ } \\
2015 \\
\end{array}$} & \multicolumn{2}{|c|}{ YSZ } & \multicolumn{2}{|c|}{ YYW } & \multirow{2}{*}{$\begin{array}{l}\mathrm{XYT} \\
2016 \\
\end{array}$} & & & \multirow{2}{*}{ No. } & \multirow{2}{*}{\begin{tabular}{|l} 
Identity \\
,$\%$
\end{tabular}} \\
\hline & & & & & & 2014 & 2015 & 2016 & & & 2015 & 2016 & 2015 & 2016 & & & & & \\
\hline \multirow{28}{*}{ ypriniformes } & \multirow{25}{*}{ Cyprinidae } & $\begin{array}{l}\text { Hypophthalmichthys } \\
\text { molitrix }\end{array}$ & & 2 & & 28 & 39 & 97 & 169 & 28 & 1 & 2 & 8 & 6 & 11 & 391 & 4.929 & EU315941 & $98-100$ \\
\hline & & Aristichthys nobilis & & & & 1 & & & 5 & & 1 & & & 1 & 1 & 9 & 0.113 & EU343733 & $99-100$ \\
\hline & & $\begin{array}{l}\text { Ctenopharyngodon } \\
\text { idellus }\end{array}$ & & 9 & & 27 & 44 & 88 & 68 & 49 & 2 & 3 & 3 & 1 & 1 & 295 & 3.719 & EU391390 & $99-100$ \\
\hline & & $\begin{array}{l}\text { Mylopharyngodon } \\
\text { piceus }\end{array}$ & & & & 8 & 7 & 12 & 13 & 7 & & & & 1 & & 48 & 0.605 & EU979307 & $99-00$ \\
\hline & & $\begin{array}{l}\text { Squaliobarbus } \\
\text { curriculus }\end{array}$ & & & & & & & 1 & 8 & & & 1 & & & 10 & 0.126 & JX910141 & 98-100 \\
\hline & & Elopichthys bambusa & & & & & & & 2 & 23 & & & & & & 25 & 0.315 & KM196112 & $99-100$ \\
\hline & & Parabramis pekinensis & & & & & & & 40 & 37 & 9 & & 19 & 7 & 14 & 126 & 1.588 & NC_022678 & $99-100$ \\
\hline & & Hemiculter bleekeri & & & & 7 & 9 & 23 & 50 & 113 & 274 & 19 & 43 & 52 & 213 & 803 & 10.122 & KT361083 & $98-100$ \\
\hline & & Hemiculter leucisculus & 40 & & & & 1 & 9 & & & & & & & & 50 & 0.630 & AY089718 & $98-100$ \\
\hline & & $\begin{array}{l}\text { Pseudolaubuca } \\
\text { engraulis }\end{array}$ & & 15 & 1 & 84 & 320 & 407 & 1 & 4 & & & & 3 & & 835 & 10.526 & NC_020462 & $99-100$ \\
\hline & & Pseudolaubuca sinensis & & & 36 & & 1 & 1 & 148 & 136 & 2 & & & & & 324 & 4.084 & KY471356 & $99-100$ \\
\hline & & Culter mongolicus & & & & 1 & & 3 & & & & & & & & 4 & 0.050 & AP009060 & 99 \\
\hline & & Culter alburnus & & & & 1 & & 6 & & 1 & & & & & & 8 & 0.101 & KX829023 & $99-100$ \\
\hline & & $\begin{array}{l}\text { Cultrichthys } \\
\text { erythropterus }\end{array}$ & & & & & & 3 & & & & & & & & 3 & 0.038 & AF051859 & 99 \\
\hline & & Coreius heterokon & & & & 49 & 30 & 93 & 5 & & & & & & & 177 & 2.231 & NC 020041 & $99-100$ \\
\hline & & Rhinogobio typus & & 9 & & 43 & 124 & 322 & 1 & 26 & 2 & & 6 & 5 & & 538 & 6.782 & KU323963 & $98-100$ \\
\hline & & Saurogobio dabryi & & & & & & 1 & & & & & & & & 1 & 0.013 & NC_ 022845 & 99 \\
\hline & & $\begin{array}{l}\text { Hemiculterella } \\
\text { sauvagei }\end{array}$ & & 5 & & 2 & 5 & 15 & & & & & & & & 27 & 0.340 & KP316066 & $98-100$ \\
\hline & & $\begin{array}{l}\begin{array}{l}\text { Saurogobio } \\
\text { gymnocheilus }\end{array} \\
\end{array}$ & & & & 1 & 28 & 35 & & 4 & 21 & & & & 9 & 98 & 1.235 & KR362925 & 98-100 \\
\hline & & Squalidus argentatus & & 1 & 31 & 1 & 38 & 63 & 13 & 111 & 36 & 5 & 3 & 20 & 171 & 493 & 6.215 & KM654503 & $98-100$ \\
\hline & & Gobiobotia filifer & & 42 & 92 & 48 & 197 & 418 & 1 & 27 & 15 & 1 & 5 & 5 & 6 & 857 & 10.803 & KP325413 & $98-100$ \\
\hline & & $\begin{array}{l}\text { Xenophysogobio } \\
\text { boulengeri }\end{array}$ & 3 & 54 & 2 & & & 16 & & & 7 & & & & & 82 & 1.034 & KM052390 & $98-100$ \\
\hline & & $\begin{array}{l}\text { Xenoplysogobio } \\
\text { nudicorpa }\end{array}$ & & 2 & & & & & & & & & & & & 2 & 0.025 & KM373519 & 98-100 \\
\hline & & Pseudobrama simoni & & & & & & & & & 20 & & & & & 20 & 0.252 & KF537571 & $99-100$ \\
\hline & & Xenocypris argentea & & & & & & & 41 & 10 & & & 4 & 1 & & 56 & 0.706 & AP009059 & $98-100$ \\
\hline & \multirow{3}{*}{ Cobitidae } & Leptobotia rubrilabris & 1 & 1 & & 1 & 5 & 15 & & & & & & & & 23 & 0.290 & AY625717 & $98-100$ \\
\hline & & Leptobotia tientaiensis & & & & & & & 3 & 32 & 3 & 9 & 6 & & 1 & 54 & 0.681 & AY625725 & $98-100$ \\
\hline & & $\begin{array}{l}\text { Leptobotia } \\
\text { microphthalrna }\end{array}$ & & 1303 & 1 & 1 & 11 & 365 & 1 & & & & & & & 1682 & 21.203 & NC_024049 & $99-100$ \\
\hline
\end{tabular}




\begin{tabular}{|c|c|c|c|c|c|c|c|c|c|c|c|c|c|c|c|c|c|c|}
\hline & Leptobotia elongata & 2 & 2 & 5 & 11 & 6 & 32 & & & & & & & & 58 & 0.731 & JQ230103 & $99-100$ \\
\hline & Leptobotia taeniaps & & 3 & 9 & 3 & 5 & 19 & 3 & 19 & 4 & & 2 & 3 & 1 & 71 & 0.895 & KM386686 & $99-100$ \\
\hline & Parabotia fasciata & & & 4 & & 18 & 13 & 10 & 30 & 2 & & & & & 77 & 0.971 & AY625709 & $98-100$ \\
\hline & Parabotia banarescui & & & & & & & 2 & 4 & & & & & & 6 & 0.076 & AY625711 & $98-100$ \\
\hline & Botia reevesae & & 1 & 2 & & & & & & & & & & & 3 & 0.038 & KU954768 & $98-100$ \\
\hline & Botia superciliaris & 11 & 37 & 87 & 3 & 22 & 110 & & & & & & & & 270 & 3.404 & AY625704 & $98-100$ \\
\hline & Paracobitis potanini & & 1 & & & & & & & & & & & & 1 & 0.013 & KP749475 & 99 \\
\hline \multirow[b]{2}{*}{ Balitoridae } & Lepturichthys fimbriata & 32 & 8 & 33 & 33 & 50 & 121 & & 35 & 4 & & & 3 & & 319 & 4.021 & KJ830772 & $99-100$ \\
\hline & Jinshaia sinensis & 26 & 7 & & 8 & 14 & 27 & & & & & & & & 82 & 1.034 & KJ739867 & $99-100$ \\
\hline & Jinshaia.abbreviata & & 2 & & & & & & & & & & & & 2 & 0.025 & DQ105211 & 99 \\
\hline luriformes & Glyptothorax sinensis & 2 & 1 & & & & & & & & & & & & 3 & 0.038 & KJ739617 & 99 \\
\hline \multicolumn{2}{|l|}{ total } & 117 & 1505 & 303 & 361 & 974 & 2314 & 577 & 704 & 403 & 39 & 100 & 108 & 428 & 7933 & 100 & & \\
\hline \multicolumn{2}{|c|}{ species number } & 8 & 20 & 12 & 21 & 21 & 26 & 20 & 20 & 16 & 6 & 11 & 13 & 11 & 40 & & & \\
\hline \multicolumn{2}{|c|}{ Shonnon H } & 1.552 & 0.686 & 1.781 & 2.317 & 2.185 & 2.441 & 2.018 & 2.506 & 1.322 & 1.396 & 1.831 & 1.759 & 1.117 & 2.710 & & & \\
\hline
\end{tabular}

2 


\section{Table 2 (on next page)}

Fish Jaccard's similarity index (JI) and river-way distances among sampled stations in the Yangtze River 
Table 2 Fish Jaccard's similarity index (JI) and river-way distances among sampled stations in the Yangtze River (Mantel test, R=-

$20.9003)$

\begin{tabular}{|c|c|c|c|c|c|c|c|c|c|}
\hline Stations & YPZ & MYB & CCS & YJJ & YYD & YJZ & YSZ & YYW & XYT \\
\hline YPZ & 0 & 780 & 1045 & 1085 & 1855 & 1955 & 2140 & 2305 & 2255 \\
\hline MYB & 0.3333 & 0 & 265 & 305 & 1075 & 1175 & 1360 & 1525 & 1475 \\
\hline CCS & 0.2667 & 0.4545 & 0 & 150 & 920 & 1020 & 1205 & 1370 & 1320 \\
\hline YJJ & 0.2800 & 0.4687 & 0.3437 & 0 & 770 & 870 & 1055 & 1220 & 1170 \\
\hline YYD & 0 & 0.2187 & 0.2800 & 0.4242 & 0 & 100 & 285 & 450 & 400 \\
\hline YJZ & 0.0370 & 0.2581 & 0.2800 & 0.4242 & 0.7391 & 0 & 185 & 350 & 300 \\
\hline YSZ & 0.0952 & 0.2593 & 0.3333 & 0.4333 & 0.5217 & 0.5652 & 0 & 165 & 115 \\
\hline YYW & 0.0909 & 0.2593 & 0.2500 & 0.3548 & 0.6500 & 0.6364 & 0.5500 & 0 & 210 \\
\hline XYT & 0 & 0.1852 & 0.1579 & 0.2667 & 0.4762 & 0.4286 & 0.6667 & 0.5625 & 0 \\
\hline
\end{tabular}

3 